

\section{Sumário}

EDITORIAL .20

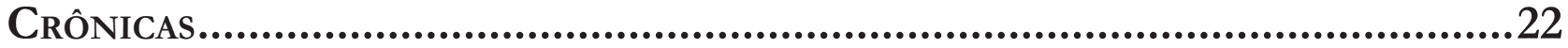

O COSTUME INTERNACIONAL COMO REFORÇO DA OBJEÇÃO BRASILEIRA À CLÁUSULA DO TRATAMENTO JUSTO E EQUITATIVO .24

Leonardo Vieira Arruda Achtschin

O PROCESSO LEGISLATIVO COMO GARANTIA PARA A OBTENÇÃo DO CONSENTIMENTO PRÉVIO DAS COMUnidades quilombolas de AlCÂNTARa

Gabriel de Oliveira Borba

Dossiê temático: Art Law and Cultural Heritage law / Direito da Arte e do Patrimônio cultural - Panorama Geral

Peoples' heritage or States' heritage? sovereignty in the UNESCO mechanism for THE SAFEGUARDING OF INTANGIBLE CULTURAL HERITAGE.

Aliki Gkana

The IMPACT OF THE UNESCO AND UNIDROIT CONVENTIONS AND THE EU DIRECTIVES ON THE INTERNATIONAL ART MARKET: AN ANALYSIS FIFTY YEARS AFTER THE INTRODUCTION OF THE OBLIGATION TO RETURN STOLEN OR ILLEGALLY EXPORTED CULTURAL GOODS 61

Geo Magri

Três pautas em destaque na agenda de diversidade Cultural da Unesco: Ambiente digiTAL, TRATAMENTO PREFERENCIAL E PARTICIPAÇÃO DA SOCIEDADE CIVIL............................76

Danilo Júnior de Oliveira, Maria Carolina Vasconcelos Oliveira e Ana Paula do Val

A 100 YEARS INSTITUTIONALIZED CULTURAL HERITAGE PROTECTION: FROM THE INSTITUTIONALIZED INTERNATIONAL COOPÉRATION INTELLECTUELLE TO THE HUMAN RIGHT TO CULTURAL HERITAGE

Lando Kirchmair 


\section{Aspectos Metodológicos do Direito da Arte e do Patrimônio}

Cultural

A proteção do PATrimônio CULTURAL EM NOVAS PERSPECTIVAS: ESTUdo COMPARAdo ENTRE A Kulturgutschutzgesetz e a Holocaust Expropriated Art Recovery Act of 2016.....111 Ardyllis Alves Soares

ArT-RELATED DispUTES AND ADR METHODS 127 Maria Beatrice Deli e Veronica Proietti

Due Diligence in Art Law and Cultural Heritage Law 150 Lisiane Feiten Wingert Ody

The Reception of Droit de Suite in International Law: Diagnosis and Remedy .... 170 Mickael R. Viglino

Direito da Arte e do Patrimônio Cultural: do Regional ao Local ....... 188

Câmara Cascudo e o legal Design - A Visualidade do Direito entre Provincianismo e GlobalizaÇão 190 Marcilio Toscano Franca Filho

A política da União Europeia no turismo: O turismo cultural e a sustentabilidade do PATRIMONNIO INDUSTRIAL PARA INTEGRAÇÃO DO BLOCO EUROPEU

Maraluce Maria Custódio e Fernando Barotti dos Santos

Diálogo entre la Corte Interamericana de Derechos Humanos y el Tribunal Europeo de Derechos Humanos en torno al Derecho humano a la identidad cultural..223 Juan Jorge Faundes

Digital ART AND THE BELT AND ROAD INITIATIVE: CHALLENGES AND OPPORTUNITIES 257 Dan Wei e Ângelo Rafael

Policing heritage crime in Latin America. .275 Naomi Oosterman e Donna Yates 
The principles of Cultural Heritage Law based on the Polish Law as an example.292 Małgorzata Joanna Węgrzak e Kamil Zeidler

Heritage Protection in INTERNATIONAL LAw AND NATIONAL LAW: INSIGHTS INTO THE CASE OF VIETNAM

Yen Thi Hong Nguyen e Dung Phuong Nguyen

THE APPROPRIATION OF THE CARIOCA INTANGIBLE CULTURAL HERITAGE BY AN ENTREPRENEURIAL LOGIC

Mário Ferreira de Pragmácio Telles

A Propósito del CARÁcter UNIVERSAL DEL aCCESO A LA CULTURA EN INTERNET: UN ANÁlisis DESDE EL PRISMA INTERNACIONAL Y LA EXPERIENCIA DEL ORDENAMIENTO JURÍDICO CUBANO 344 Janny Carrasco Medina

Direito Humanitário e Arte

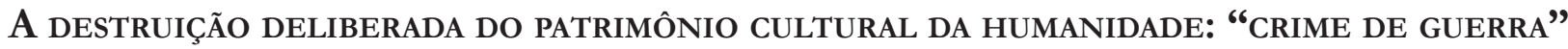
OU "CRIME CONTRA A HUMANIDADE"? Juliette Robichez

Protection OF CULTURAL PROPERTY UNDER INTERNATIONAL HUMANITARIAN LAW: EMERGING TRENDS

Niteesh Kumar Upadhyay e Mahak Rathee

Direito do Mar/Marítimo e Arte.

The underwater Cultural heritage Regime: SOME PROBlems AND POSSible SOlutions. 412 Elina Moustaira

El ROL DEL DERECHO EN LA CONSTRUCCIÓN DEL PATRIMONIO CULTURAL SUBACUÁTICO: APRECiaciones a partirdel estudio del CASo de la Corbeta Inglesa SwifT en Argentina .. 424 Norma Elizabeth Levrand e Nadia Bressan Bernhardt 
INDIGENOUS REFUGEES AND CULTURAL EROSION: POSSIBILITIES AND LIMITS OF INTERNATIONAL REFUGEE AND INDIGENOUS PEOPLES LAW IN THE PROTECTION OF INDIGENOUS CULTURAL EXPRESSIONS RELATED TO TRADITIONAL LAND AND NATIVE LANGUAGE. .440 Rickson Rios Figueira

O RETRATO DE EDMOND BELAMY E A INTERFACE ENTRE ARTE E INTELIGENCIA ARTIFICIAL: POR UMA NOVA DEFINIÇÃo DE AUTORIA E DIREITOS DE PROPRIEDADE INTELECTUAL

Marla Meneses do Amaral Leite Mangiolardo, Patrícia Silva de Almeida e Jonathan Barros Vita

Argumentative aspects of Declaration on the Importance and Value of Universal Museums (2002) 479

Agnieszka Plata

A DestinaÇão dos bens CUlturais EM PROCESSOS PENAIS: A ARTE COMO REPARAÇÃo COLETIVA 488

Inês Virgínia Prado Soares e Otavio Venturini

A Justiça de Pieter Bruegel: direito, violência e a venda nos (nossos) olhos. .501 Rafael Lazzarotto Simioni e Cícero Krupp

Artigos Sobre outros temas

DEVERES INTERNACIONAIS E OBRIGAÇÕES SOCIOAMBIENTAIS PARA EMPRESAS MULTI E TRANSNACIONAIS

Luísa Cortat Simonetti Gonçalves e Adriano Sant'Ana Pedra

Maternidade por substituição: perspectivas da ConferênCia da Haia e suas potenciais INFLUÊNCIAS NO REGRAMENTO BRASILEIRO

Tatiana de A. F. R. Cardoso Squeff e Fernanda Rezende Martins

EL (LARGO) CAMINO DE RECONOCIMIENTO Y EJECUCIÓN DE LAUDOS ARBITRALES DE INVERSIÓN

Thiago Paluma, Ivette Esis e Gabriel Briceño 
A INTERPRETAÇÃo EVOLUTIVA DA CONVENÇÃo AMERICANA SOBRE DiREITOS HUMANOS: UMA REVISÃO DOCUMENTAL DO PERÍODO 1988-2018

Breno Baía Magalhães

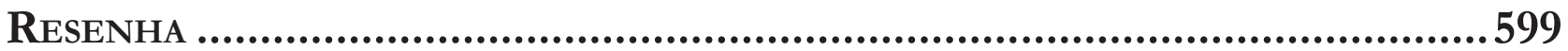

Autonomous Weapons Systems and InTERnATIONAL LAw: A STUDY ON HUMAN-MACHINE INTERACTIONS IN ETHICALLY AND LEGALLY SENSITIVE DOMAINS

Aziz Tuffi Saliba e Lutiana Valadares Fernandes Barbosa 


\title{
The appropriation of the carioca intangible cultural heritage by an entrepreneurial logic*
}

\section{A apropriação do patrimônio cultural intangível da carioca por uma lógica empresarial}

\author{
Mário Ferreira de Pragmácio Telles**
}

\begin{abstract}
This paper focuses on the means by which the City Hall of Rio Janeiro implemented a policy for the preservation of local cultural heritage and used legal instruments available to the protection of intangible heritage, notably from 2013, as of the creation of a new category: The Traditional and Notable Economic Activities`s Book of Registry. The research is based on the debate about the conception of the Intangible Cultural Heritage (ICH) as an analytical category, in order to recognize that the $\mathrm{ICH}$ carries a challenging potential capable of supporting the struggles of historically subalternized groups and subjects, thus revealing the essentially political nature of this category. The development of the research intends to demonstrate that Rio `s intangible heritage was captured by the entrepreneurial logic, which led to the neutralization of the challenging power of this category and permitted the beginning of the memory deletion process of those historically subalternized subjects and groups.
\end{abstract}

Keywords: Intangible Cultural Heritage. Registry. Traditional and remarkable economic activities. Rio de Janeiro city. Cultural policy.

\section{Resumo}

Este artigo enfoca os meios pelos quais a Prefeitura do Rio de Janeiro implementou uma política de preservação do patrimônio cultural local e utilizou os instrumentos jurídicos disponíveis para a proteção do patrimônio imaterial, notadamente a partir de 2013, a partir da criação de uma nova categoria: O Livro de Registro de Atividades Econômicas Tradicionais e Notáveis. A pesquisa se baseia no debate sobre a concepção de Patrimônio Cultural Imaterial (PCI) como categoria analítica, a fim de reconhecer que o PCI carrega um potencial desafiador capaz de sustentar as lutas de grupos e sujeitos historicamente subalternizados, revelando o que é essencialmente natureza política desta categoria. O desenvolvimento da pesquisa pretende demonstrar que o patrimônio imaterial do Rio foi capturado pela lógica empresarial, o que levou à neutralização do poder desafiador dessa categoria e permitiu o início do processo de apagamento da memória daqueles sujeitos e grupos historicamente subalternizados.

** PhD in Law by PUC-Rio, professor at Art Department of Fluminense Federal University and at the National Institute of Historical and Artistic Heritage (IPHAN) for the Professional Master program.

E-mail: mariopragmacio@id.uff.br 
Palavras-chave: patrimônio cultural intangível; registro; atividades econômicas tradicionais e registráveis; cidade do Rio de Janeiro; política cultural.

\section{Introduction}

Cultural heritage has increasingly gained attention from the legal world, whereas academic production under the prism of Law is still very restricted, especially regarding Intangible Cultural Heritage (ICH).

Accordingly, there are few studies that address the legal issues of the ICH at a local level, particularly the impact of the application of instruments aimed at the preservation of intangible cultural assets in city life.

In recent years, Rio de Janeiro has undergone an intense transformation process therefore impacting social, environmental, urban, economic and cultural aspects to a great extent, especially due to international mega-events that were held in the city, namely the 2014 World Cup and the 2016 Olympic Games. In this context, cultural heritage, rather than being regarded as something unwanted, as an obstacle, was instead positively incorporated and reintroduced as an advantage in the creation of a new city model.

Be that as it may, this process is not perceivable at a first glance. It often appears to be beneficial to the preservation of cultural heritage, for it dedicates an unusual amount of attention to this field by declaring, for example, a series of cultural assets as Carioca intangible heritage.

However, the ICH in this context has been fulfilling the role of distinguishing Rio de Janeiro from other cities, within a global market logic, praising the singularity expressed in cultural goods of intangible nature that endorses the creation of a so-called Carioca brand.

This endorsement is evidently initiated in 2013, through the creation of a new intangible asset's recognition category: The Traditional and Notable Economic Activities (AETN). This new category recognizes as part of Rio de Janeiro's intangible cultural heritage such as chapelarias ${ }^{1}$, confectioneries, cigar shops, tradi-

Chapelaria is a hat shop; the manufacture and sale of hats or headgear; a common trade in Rio de Janeiro. The hat maker or manufacturer is referred to as a chapeleiro or chapeleira, which translates into a hatter (as in Alice in Wonderland). tional pubs, among other small businesses and services of similar nature.

Thus, in order to analyze the nuances and fluctuations of this recent category, i.e., Traditional and Notable Economic Activities, the findings of this article are solely based on the municipality of Rio de Janeiro, considering two specific frameworks so as to enable the research: a territorial and a time framework.

The first framework refers to the territory where the assets recognized as Traditional and Notable Economic Activities are concentrated: Downtown Rio de Janeiro ${ }^{2}$. According to João Domingues ${ }^{3}$ classification $^{4}$, the second framework (time) refers to the period corresponding to the Eduardo Paes Government in Rio de Janeiro (from 2009 to 2016). This framework was specifically chosen considering the urban and heritage policies implemented in this interregnum and due to the economical and geographical spread that occurred in the city of Rio de Janeiro, enhanced by the announcement and the realization of these great international events, which directly impacted the preservation of cultural heritage.

While this measure is welcomed, due to the insertion of intangible assets as constituents of the current notion of cultural heritage, as established in article 216 of the 1988 Brazilian Federal Constitution, difficulties arise in the adaptation and implementation of this new paradigm in local politics. What happens when the $\mathrm{ICH}$ is used in this specific context?

This article will address issues related to the relationship between intangible cultural heritage and the entrepreneurial logic that prevailed in the urban planning of the city of Rio de Janeiro, especially during the

2 See Figure 1. Only two assets selected in according to this policy are located outside Downtown Rio, located instead in the neighborhood of Copacabana (Zona Sul), namely the Confectionery and Restaurant Cirandinha - Nossa Senhora de Copacabana Ave., no. 719; and La Marquise Confectionery - Carvalho de Mendonça Street, no. 29, which were included in the Register of Traditional Businesses. Notwithstanding this exception, both were excluded from our clipping, which covers Downtown Rio de Janeiro, because it is explicitly the prioritized region of this local policy.

3 DOMINGUES, João Luiz Pereira. A história institucional recente da política de patrimônio cultural na cidade do Rio de Janeiro: versões protecionistas, versões empreendedoras. Antiteses, v. 9, n. 17, p. 222-245, jan./jun. 2016.

4 Domingues (2016) separates the preservationist policy of the city of Rio de Janeiro in two phases, that of the preservationist and the enterprising, the latter being subdivided into two periods - César Maia Government and Eduardo Paes Government. 
Paes Government ${ }^{5}$ and considering the Chapelaria Porto reference case, one of the assets of intangible nature registered under the category of Traditional and Notable Economic Activity (AETN).

\section{The standardization of the city of Rio de Janeiro and urban entrepreneurship}

As opposed to the significant amount of work and research devoted to intangible cultural heritage, especially those that that are based on an anthropological tradition $^{6}$, the ideas developed in this article are not directly linked to the rural context or concerning a singular cosmogony or social system. On the contrary, they refer to the application and understanding of the ICH in an urban context of a large metropolis - Rio de Janeiro - closely connected to the western capitalistic system ${ }^{7} .8$

Studies that transition between Law and Urbanism are essential when analyzing the impact of intangible cultural heritage policies in the city context. In the legal field, the emergence of a notion of a right to the city is especially significant for it will help in situating the preservation of heritage in an urban context as a common right ${ }^{9}$. On the other hand, from an urbanistic point of view, within the debate on a right to the city, research

Eduardo Paes was elected mayor of Rio de Janeiro twice, remaining in office from 2009 -2016.

${ }_{6}$ With the exception of the so-called Urban Anthropology. On the subject, see VELHO, Gilberto. Antropologia urbana: interdisciplinaridade e fronteiras do conhecimento. Mana, Rio de Janeiro, v. 17. n. 1, abr. 2011.

SOUZA FILHO, Carlos Frederico Marés. Tombamento e registro: dois instrumentos de proteção. In: FERNANDES, Edésio; ALFONSIN, Betânia. Revisitando o instituto do tombamento. Belo Horizonte: Fórum, 2010. p. 165.

8 On the capitalistic system, Marés de Souza Filho (2010, p. 165) makes an important reservation on cultural heritage studies, for "this is evidently within the context of law built by modernity, capitalist-based. The theory would probably be different if it were made in a legal system which did not maintain private property of material goods, especially that of the land itself.". He concluded: "a system in which land would be refractory to private appropriation, both cultural and natural goods would be protected in a much simpler legal way".

9 Other areas, such as Environmental Law (cultural environment, which is dedicated to cultural heritage) and Cultural Law (considers the preservation of heritage as one of cultural rights, which, as we know, is a neglected category of human rights) also do, but the right to the city contextualizes it historically and territorially in the city. and articles that discuss models to comprehend contemporary cities, particularly that of a standard city are appropriate $^{10}$.

The concept of a right to the city as presented in this article differs from what was initially pioneered by the geographer Henri Lefebvre in the 1967 essay entitled "Le droit à la Ville" ", written for the commemorations of the centenary of the publication Capital, Volume I by Karl Marx ${ }^{12}$. This work, which was written one year before the "1968 irruption", as David Harvey ${ }^{13}$ pointed out, briefly touched upon the political role of social movements in urban life, evidently, in a Marxist perspective ${ }^{14}$.

In the present article an inspired but distinct vision is adopted of Lefebvre's right to the city, evidencing its legal dimensions. Accordingly, this article is based on the formulations made by Rosângela Cavallazzi ${ }^{15}$, who has been coordinating a series of researches in Law and Urbanism ${ }^{16}$.

According to Cavallazzi ${ }^{17}$, in Brazil, the right to the city originally emerges from Urban Law as a field of

10 CAVALLAZZI, Rosângela Lunaderlli. Cidade Standard: desafios da paisagem em movimento. In: AHMED, Flávio; SOARES, Inês Virgínia Prado (org.). Bens culturais e cidades sustentáveis. Rio de Janeiro: Lumen Juris, 2016.

11 LEFEBVRE, Henri. O direito à cidade. São Paulo: Centauro, 2010. 12 HARVEY, David. Cidades rebeldes: do direito à cidade à revolução urbana. São Paulo: Martins Fontes, 2014. p. 11.

13 HARVEY, David. Cidades rebeldes: do direito à cidade à revolução urbana. São Paulo: Martins Fontes, 2014. p. 13.

14 In order to deepen the concept of the right to the city as mentioned by Lefebvre, historically situating it, read more of the ideas of David Harvey in the work Cidades Rebeldes: o direito à cidade à revolução urbana (Rebel Cities: a city's right to urban revolution (2014), originally published in 2012 , especially the first chapter, dedicated to 'the right to the city', in which Harvey dialogues with the Lefebvrian idea, presenting strategies needed for action in the post-crisis context of 2008, understanding that social movements should focus on controlling and democratizing surplus capitalist production.

15 CAVALLAZZI, Rosângela Lunaderlli. Perspectivas contemporâneas do patrimônio cultural: paisagem urbana e tombamento. In: FERNANDES, Edésio; ALFONSIN, Betânia. Revisitando o instituto do tombamento. Belo Horizonte: Fórum, 2010.; CAVALLAZZI, Rosângela Lunaderlli. Cidade Standard: desafios da paisagem em movimento. In: AHMED, Flávio; SOARES, Inês Virgínia Prado (org.). Bens culturais e cidades sustentáveis. Rio de Janeiro: Lumen Juris, 2016.; CAVALLAZZI, Rosângela Lunaderlli; FAUTH, Gabriela (coord.). Cidade Standard e novas vulnerabilidades. Rio de Janeiro: PROURB, 2018.

16 See the collection 'Law and Urbanism', volumes 1 and 2 (Cavallazzi and Ribeiro, 2010; Cavallazzi and Ayres, 2012).

17 CAVALLAZZI, Rosângela Lunaderlli. Perspectivas contemporâneas do patrimônio cultural: paisagem urbana e tombamento. In: FERNANDES, Edésio; ALFONSIN, Betânia. Revisitando o instituto do tombamento. Belo Horizonte: Fórum, 2010. p. 131. 
knowledge in applied sciences, especially with the 1988 Brazilian Federal Constitution and mainly as a result of the enactment of the City Statute, the Civil Code of 2002, and with the establishment of the Ministry of Cities at a federal level.

Rosângela Cavallazzi ${ }^{18}$ argues that the right to the city is the core of Urban Law, and it is composed of several rights, which include, among others ${ }^{19}$, the preservation of the cultural, historical and landscape heritage, which will thereof be referred to only as cultural heritage, provided that all historical and landscape heritage is, in turn, cultural.

The concept of the right to the city, in itself the preservation of cultural heritage, is useful for comprehending the patrimonizalization process of cultural assets that occur in large urban centers, such as Rio de Janeiro, supporting the analysis of the Carioca preservationist policies $^{20}$.

The comprehension of a standard city, also approached by Cavallazzi in her study of the right to the city, is a crucial factor for the understanding of what is meant in the present article as a "contemporary Rio de Janeiro". In the essay "Standard City: challenges of a landscape in motion", Rosângela Cavallazzi ${ }^{21}$ clearly defines the fundamentals that form this particular city model. For the author, the standard city results in formatted cities that are sensitive to the logic of globalization ${ }^{22}$, in which the environment and urban social relations become entrapped in the referred market model ${ }^{23}$.

18 CAVALLAZZI, Rosângela Lunaderlli. Perspectivas contemporâneas do patrimônio cultural: paisagem urbana e tombamento. In: FERNANDES, Edésio; ALFONSIN, Betânia. Revisitando o instituto do tombamento. Belo Horizonte: Fórum, 2010. p. 130.

19 The right to housing, education, work, health, public services, leisure, security, public transport, the natural and developed environment also integrate the concept of the 'right to the city'. The "The Global Charter for the Right to the City", drafted in 2001 by the participants of the First World Social Forum, is a great reference for the identification of the mentioned rights.

20 In the city of Rio de Janeiro, the urban norms, among them the Directive Plan, deal with intangible cultural heritage, considering the respective preservation mechanisms as instruments of urban policy. 21 CAVALLAZZI, Rosângela Lunaderlli. Cidade Standard: desafios da paisagem em movimento. In: AHMED, Flávio; SOARES, Inês Virgínia Prado (org.). Bens culturais e cidades sustentáveis. Rio de Janeiro: Lumen Juris, 2016.

22 The globalization logic referenced by Cavallazzi is shared by Milton Santos. Such logic evidences, above all, its perverse characteristics. See: Santos (2003).

23 On the subject, see the collective work Cidade standard e novas vulnerabilidades (Standard City and New Vulnerabilities), coordinated by Cavallazzi and Gabriela Fauth (2018).
As explained by the Hobsbawnian sense of ideals ${ }^{24}$, standardization fails to acknowledge the history of residents and creates a new set of traditions, thus unifying the memory of the $\operatorname{city}^{25}$. Cultural heritage would hold a strategic role considering such a scenario, created due to the standardization ${ }^{26}$, either to emphasize the standardizing function, or to foster hope ${ }^{28}$ in order to provide visibility for historically vulnerable and inferior groups.

In a standard city, the inhabitants adhere to the city ${ }^{29}$. The preservation of cultural heritage is imposed upon, for it is preestablished regardless of any kind of negotiation, participation or response from individuals deemed as vulnerable. Therefore, a standard city is also composed by cultural heritage.

This referred to market model results in new vulnerabilities and the consequent shielding to the right to the city, concept established in the present article as myriad of rights, which include the preservation of cultural heritage as a common right.

The right to cultural heritage (or the right to preserve cultural heritage) is not fulfilled in the standard city.

24 HOBSBAWM, E.; RANGER, T. A invenção das tradições. Rio de Janeiro: Paz e Terra, 1997.

25 CAVALLAZZI, Rosângela Lunaderlli. Cidade Standard: desafios da paisagem em movimento. In: AHMED, Flávio; SOARES, Inês Virgínia Prado (org.). Bens culturais e cidades sustentáveis. Rio de Janeiro: Lumen Juris, 2016.

26 CERTEAU, Michel de. A invenção do cotidiano: artes de fazer. 14. ed. Rio de Janeiro: Vozes, 2008. v. 1. p. 100.

27 Michel de Certeau concepts for 'strategy' and 'tactics' help in comprehending this double possibility. Certeau defines as strategy the relationships of force that an individual, who is fully capable and seeks power, when isolated uses others or turns to manipulations tactics; while tactics is "the movement 'within the enemy's field of view' [...], and in a space controlled by the enemy. [...] It strikes blow by blow. Takes advantage of the 'occasions' and is dependent of them, with no basis for stocking benefits and for increasing the property and to anticipate exits. Its gains are not preserved, however. This non-place allows for its mobility, but is also open to the hazards of time, so as to capture in flight the possibilities offered by an instant. One must make use, vigilantly, of the failures that the private conjunctures open in the surveillance of the proprietary power. Then it [tactics, as defined by Certeau] goes hunting, so to speak. Creating surprises, and is capable of landing itself where nobody expected it to be. It's cunning.". CERTEAU, Michel de. A invenção do cotidiano: artes de fazer. 14. ed. Rio de Janeiro: Vozes, 2008. v. 1. p. 100-101.

28 HARVEY, David. A produção capitalista do espaço. São Paulo: Annablus, 2006.

29 CAVALLAZZI, Rosângela Lunaderlli. Cidade Standard: desafios da paisagem em movimento. In: AHMED, Flávio; SOARES, Inês Virgínia Prado (org.). Bens culturais e cidades sustentáveis. Rio de Janeiro: Lumen Juris, 2016. p. 7. 
As perceived by Cavallazzi30, "the city as an urban center is transformed into an enterprise; it replicates the market logic. A corporative ecstasy is established that translates into production and consumption, where one recognizes the other only as another market player.". Thus, "its urban center becomes diverse due to the influence of real estate agents and both market tendencies or demands, resulting in new competing centricities.".

Therefore, according to Cavallazzii ${ }^{31}$, the contemporary city of Rio de Janeiro can be deemed as a standard city. According to the models proposed by Cavallazzi, preservationist actions directed at intangible assets that are part of the Carioca cultural heritage will be further analyzed in this article.

In order to reinforce and deepen this standardized city perspective while taking into account the local experience of recent years, works developed by the author João Domingues ${ }^{32}$, specifically his article on cultural heritage: "A bistória institucional recente da política de patrimônio cultural na cidade do Rio de Janeiro: versões protecionistas, versões empreendedoras" ${ }^{33}$, will also be considered. Domingues has been researching cultural policies and urban sociology, and his ideas combined with those expressed by Cavallazzi strengthen the arguments presented in this article.

In the mentioned work, Domingues ${ }^{34}$ strives to understand the influence urban entrepreneurship ${ }^{3536}$ has

30 CAVALLAZZI, Rosângela Lunaderlli. Cidade Standard: desafios da paisagem em movimento. In: AHMED, Flávio; SOARES, Inês Virgínia Prado (org.). Bens culturais e cidades sustentáveis. Rio de Janeiro: Lumen Juris, 2016. p. 9.

31 CAVALLAZZI, Rosângela Lunaderlli. Cidade Standard: desafios da paisagem em movimento. In: AHMED, Flávio; SOARES, Inês Virgínia Prado (org.). Bens culturais e cidades sustentáveis. Rio de Janeiro: Lumen Juris, 2016.

32 DOMINGUES, João Luiz Pereira. A história institucional recente da política de patrimônio cultural na cidade do Rio de Janeiro: versões protecionistas, versões empreendedoras. Antíteses, v. 9, n. 17, p. 222-245, jan./jun. 2016.

33 Translation: "The recent institutional history on cultural heritage policies in the city of Rio de Janeiro: protectionist versions, entrepreneurial versions".

34 DOMINGUES, João Luiz Pereira. A história institucional recente da política de patrimônio cultural na cidade do Rio de Janeiro: versões protecionistas, versões empreendedoras. Antíteses, v. 9, n. 17, p. 222-245, jan./jun. 2016.

35 HARVEY, David. A produção capitalista do espaço. São Paulo: Annablus, 2006.; HARVEY, David. Cidades rebeldes: do direito à cidade à revolução urbana. São Paulo: Martins Fontes, 2014.

36 Harvey elaborates on the concept of urban entrepreneurship, which was worked with by Domingues (2016) to analyze the case of Rio de Janeiro in the publication A produção capitalista do espaço (2006), which translates into The Capitalist Production of Territory, as well as in Cidades Rebeldes [... (2014), which translates into Rebel Cities on the preservation policies regarding the Carioca cultural heritage. The author provides readers with an important chronology of the existing local preservation policies, which historically define the time frame where the assets recognized as traditional and notable economic activities are included ${ }^{37}$.

Domingues ${ }^{38}$ divides the institutional history of cultural policy on the Carioca heritage in two phases (or versions), which he called: (a) protectionist and (b) urban entrepreneurial.

The protectionist version is that corresponding to the end of the seventies, which culminated in the inauguration of urbanistic instruments, such as the Cultural Strip (Corredor Cultural) and the Protection Area of the Cultural Environment (APAC), aimed at curbing the destruction of certain parts of the city, i.e. the downtown areas.

Downtown Rio has also stood out as a priority area for the implementation of actions that preserve cultural heritage, mainly due to pressure from the residents' associations. Domingues ${ }^{39}$ recalls that "since the city did not have the legal instruments for protecting heritage [...], in order to make the implementation feasible, zoning laws and ground occupation strategies were necessary.”. Only in 1980, with Law no. 166, which created the possibility for heritage listing and established the Municipal Council for the Protection of Cultural Heritage "that the elaboration of heritage policies concerned with the urban aspects of Rio de Janeiro became viable". ${ }^{40}$

Considered a first phase, Domingues ${ }^{41}$ argues that "it corresponded to the choices made by institutes ai-

[...]. See: HARVEY, David. From managerialism to entrepreneurialism: the transformation of urban governance in late capitalism. Geographic Annaler, v. 71B, p. 3-17, 1989.

37 Refers to the Eduardo Paes governing Era (2009-2016).

38 DOMINGUES, João Luiz Pereira. A história institucional recente da política de patrimônio cultural na cidade do Rio de Janeiro: versões protecionistas, versões empreendedoras. Antíteses, v. 9, n. 17, p. 222-245, jan./jun. 2016.

39 DOMINGUES, João Luiz Pereira. A história institucional recente da política de patrimônio cultural na cidade do Rio de Janeiro: versões protecionistas, versões empreendedoras. Antíteses, v. 9, n. 17, p. 222-245, jan./jun. 2016. p. 226.

40 DOMINGUES, João Luiz Pereira. A história institucional recente da política de patrimônio cultural na cidade do Rio de Janeiro: versões protecionistas, versões empreendedoras. Antiteses, v. 9, n. 17, p. 222-245, jan./jun. 2016. p. 226.

41 DOMINGUES, João Luiz Pereira. A história institucional recente da política de patrimônio cultural na cidade do Rio de Janeiro: versões protecionistas, versões empreendedoras. Antíteses, v. 9, n. 17, p. 222-245, jan./jun. 2016. p. 225. 
med at protecting the "national memory", among them, the National Institute of Historic and Artistic Heritage (IPHAN). Furthermore, "these conceptions flooded Rio's legislations and heritage selection, leading them to include articles on real estate protection and limitations for civil constructions". ${ }^{42}$

The second phase, also according to Domingues' classification is called the Carioca urban entrepreneurship. This entrepreneurial version is composed of two distinct moments that are divided according to two of Rio de Janeiro's mayors. First, during the César Maia era, from 1993 to $2008^{43}$. Throughout these years, investments were directly connected to urban marketing and applied to the construction of physical space ${ }^{44}$. Secondly, throughout the Eduardo Paes era, which began in 2009, and when creative economy ${ }^{45}$ and structural

42 DOMINGUES, João Luiz Pereira. A história institucional recente da política de patrimônio cultural na cidade do Rio de Janeiro: versões protecionistas, versões empreendedoras. Antíteses, v. 9, n. 17, p. 222-245, jan./jun. 2016. p. 225.

43 César Maia was elected as mayor of Rio de Janeiro twice, same as Eduardo Paes.

44 In Domingues understanding "For such a project, culture as one of its fundamental axes. The change in urban management repositions the city's 'unique qualities' in order to stand out in relation to other cities, whether they be natural cities, existing architectural complexes or yet to be built, also considering its specialized services, its diversity and cultural attractions. The process also incorporates a very subtle change in the field of business advertising and in new forms of consumption analysis. With the branding technique, advertisers have found a new way of managing the business brand, radically transforming the advertising language. Initially, when companies invested in advertising, the main focus was on information on the advertised products, operating on the expansion of consumer markets. Branding, however, associates the product with a lifestyle, as a distinctive link to the loyalty and constant movement of their markets.”. DOMINGUES, João Luiz Pereira. A história institucional recente da política de patrimônio cultural na cidade do Rio de Janeiro: versões protecionistas, versões empreendedoras. Antiteses, v. 9, n. 17, p. 222-245, jan./jun. 2016. p. 223-224.

45 Creative Economy is an Anglo-Saxon concept, initially implemented in Australia (Creative Nation project) and in the United Kingdom (by the policy called Creative Industries Task Force), brought to Brazil as a public policy in the Dilma Government, with the creation of the Department of the Creative Economy. The creative economy encompasses several "creative sectors" such as fashion, electronic games, theater, cinema, design and cultural heritage. On the subject, in a critical perspective, see DOMINGUES, João Luiz Pereira; LOPES, Guilherme. Economia Criativa e trabalho cultural: notas sobre as políticas culturais brasileiras e nos marcos do capitalismo contemporâneo. In: RUBIM, Antônio Albino Canelas; BARBALHO, Alexandre; CALABRE, Lia (orgs.). Politicas culturais no governo Dilma. Salvador: EDUFBA, 2015. Translation of cited titles: Creative Economy and cultural work: notes on Brazilian cultural policies within the framework of contemporary capitalism. In: Cultural policies in the Dilma government. changes in patrimonial management of the city of Rio de Janeiro complemented the ongoing movement ${ }^{46}$.

The proposed time framework in this article is based on the classifications also determined by João Domingues. It includes Eduardo Paes Government (2009-2016), which is part of the second moment of the entrepreneurial version of Rio de Janeiro's heritage policy.

In addition, the proposed territorial framework, i.e. Downtown Rio de Janeiro, is also present in João Domingues criticism when he argues on the ennobling characteristics of creative economy, through the analysis of the "Strategic Plan of the City of Rio de Janeiro post2016: an integrated and competitive city"4748, a document that explains the predilection for Downtown Rio:

In the post-2016 Rio strategic plan, the creative logic refers to specific interventions in Downtown Rio, shifting the "Product Barra" to the central region of the city. The Post-2016 Rio focuses on the deduction of investments in urban enclaves, highlighting the cultural attractions responsible for the intervention in the Port Area - Rio Art Museum and Museum of Tomorrow - and in the revitalization of Praça Tiradentes and Lapa. It is possible, however, that this dimension of urban policies guided by the initiative of adding cultural attractions can lead to the process of gentrification in the Downtown area of the city, either in the "revision of building parameters in empty lots" or in the "implementation of public notices for concessions on real estates defined as economically strategic.". 49

Predictably, the territorial spaces where assets recognized as Traditional and Notable Economic Activities

46 DOMINGUES, João Luiz Pereira. A história institucional recente da política de patrimônio cultural na cidade do Rio de Janeiro: versões protecionistas, versões empreendedoras. Antíteses, v. 9, n. 17, p. 222-245, jan./jun. 2016. p. 229.

47 RIO DE JANEIRO [Município]. Plano Estratégico da cidade do Rio de Janeiro pós-2016: o Rio mais integrado e competitivo. Rio de Janeiro, 2010. p. 208.

48 João Domingues explains that "during Eduardo Paes first term of office, the city hall launched the Post-2016 plan, an integrated and competitive plan for Rio de Janeiro. This plan has 56 goals and 58 initiatives, and its main objective is to transform Rio de Janeiro into a 'national reference in the excellence of the business environment with outstanding leadership in attracting and maintaining productive investments' (RIO DE JANEIRO, 2010, p. 16).”. DOMINGUES, João Luiz Pereira. A história institucional recente da política de patrimônio cultural na cidade do Rio de Janeiro: versões protecionistas, versões empreendedoras. Antiteses, v. 9, n. 17, p. 222-245, jan./ jun. 2016. p. 232.

49 DOMINGUES, João Luiz Pereira. A história institucional recente da política de patrimônio cultural na cidade do Rio de Janeiro: versões protecionistas, versões empreendedoras. Antiteses, v. 9, n. 17, p. 222-245, jan./jun. 2016. p. 241. 
(AETN) are located in Downtown Rio de Janeiro, near the Port Area and bordering Praça Tiradentes. This is due to a deliberate policy that considers local cultural heritage as an instrument of urban entrepreneurship and recognizes those that hold ICH as entrepreneurs.

Washington Fajardo, former president of the Rio Institute of Humanity Heritage (IRPH), in an interview with FGV Projects ${ }^{50}$, addresses the priority in making Downtown Rio the main focus area for implementing heritage (both tangible and intangible) policies:

\begin{abstract}
The actions undertaken by Rio de Janeiro's City Hall are strategic for the urban development of the city. In prioritizing Downtown Rio, through Porto Maravilha, it alters the logic of urban development of the city in force during the last 40 years, which is that of the expansion of the city. This has both a tangible and intangible impact. The tangible effect was the improvement of our Downtown area, which had increased visits and developed tourism. A concrete example: restaurants that were only open during weekdays, are now working during weekends as well. There is also an intangible result. Over the last 40 years, we have understood that expanding the city was to promote economic development. We had a way of thinking that associated city growth and expansion with positivity because it meant getting richer and developing society. This is a misconception. The intangible dimension in recovering the Downtown area can be translated into a change in the way we once thought of the city. We begin to acknowledge a city we already had with a new perspective when it comes to occupation, thus promoting economic development. New businesses are opened, people are able to now live closer to work, consequently creating a more sustainable urban ecosystem, more resilient to economic crises, environmental and social issues.
\end{abstract}

According to Domingues ${ }^{51}$, "this project is conditioned to the concentration of capital investments in selected areas of the city, linked to a high selection of normative and symbolic models so as to maintain a certain image of the endeavored city.". Inspired by David Harvey $^{52}$, João Domingues ${ }^{53}$ argues that "this new plan-

\footnotetext{
50 Interview with Washington Fajardo. Available at: http:/ / fovprojetos.fgv.br/noticias/entrevista-com-washington-fajardo. Access on: Jan. 19, 2018.

51 DOMINGUES, João Luiz Pereira. A história institucional recente da política de patrimônio cultural na cidade do Rio de Janeiro: versões protecionistas, versões empreendedoras. Antíteses, v. 9, n. 17, p. 222-245, jan./jun. 2016. p. 224.

52 HARVEY, David. A produção capitalista do espaço. São Paulo: Annablus, 2006.

53 DOMINGUES, João Luiz Pereira. A história institucional recente da política de patrimônio cultural na cidade do Rio de Janeiro:
}

ning model instates a new and robust vocabulary for the understanding of an entrepreneurial city, exploring the locational advantages for offering goods and services and for attracting financial capital.”.

Thus, "for the culture universe, this new model of urban regulation would guide the commodification of part of the city as a unitary image (City Marketing), based on the selection of local identities and a highly controlled social use of urban space.". ${ }^{54}$

David Harvey ${ }^{55}$, according to Bourdieu's notions, but applying them in a collective perspective, contends that the collective capital of cities like Rio de Janeiro is a form of distinction in the global marketplace. Therefore, they constitute distinctive trademarks ${ }^{56}$, which praise the singularities and often rely on cultural heritage and memory as structuring elements of the so-called urban entrepreneurship.

On the other hand, Harvey presages the ambiguity and contradiction of this phenomenon. In order to exemplify, Harvey ${ }^{57}$ mentions the French wine production to explain monopolized income ${ }^{58}$ in the chapter "Arte da renda" from the book "Cidades Rebeldes [...]", in which he calls attention to a new phenomenon of contemporary capitalism. In the mentioned phenomenon, instead of unifying or destroying, capital is invested in what presents certain 'unique', 'singular' and 'authentic' characteristics, demonstrating a new approach when considering the relation between intangible heritage, market and globalization:

Nevertheless, income or profit stemming from monopoly is in itself a contradictory modality. The quest

versões protecionistas, versões empreendedoras. Antíteses, v. 9, n. 17, p. 222-245, jan./jun. 2016. p. 223.

54 DOMINGUES, João Luiz Pereira. A história institucional recente da política de patrimônio cultural na cidade do Rio de Janeiro: versões protecionistas, versões empreendedoras. Antíteses, v. 9, n. 17, p. 222-245, jan./jun. 2016. p. 264.

55 HARVEY, David. Cidades rebeldes: do direito à cidade à revolução urbana. São Paulo: Martins Fontes, 2014. p. 193.

56 HARVEY, David. Cidades rebeldes: do direito à cidade à revolução urbana. São Paulo: Martins Fontes, 2014. p. 194-195.

57 HARVEY, David. Cidades rebeldes: do direito à cidade à revolução urbana. São Paulo: Martins Fontes, 2014.

58 In order to analyze the relationship between the tendency to create monopolies in certain economic sectors and cultural singularities, Harvey studies the wine market and the repercussions of the French wine terroir, which carries a strong tradition and economic impact, as opposed to the Australian wines that are characteristically distinct and deprived of the so-called 'authenticity of the terroir. They make use of other categories to counteract the distinctive forms that used in wines produced in a certain region in France, where specific techniques are applied. 
for such an income causes global capital to value distinctive local initiatives - indeed, in some cases, the more distinctive and, especially nowadays, the more transgressive these initiatives are, the better. It also leads to the appreciation of singularity, authenticity, particularity, originality and all other dimensions of social life that are incompatible with the presumed homogeneity caused by the production of goods. Furthermore, if the investment isn't intended to completely destroy the singularity which allows for the appropriation of monopoly revenues (and there are many circumstances in which this occurred and those involved were severely condemned for it), then it must be used in a way that it defends differentiation, allowing for the development of a divergent and, to some extent, uncontrollable local culture that may be antagonistic to its own functioning.

Due to these characteristics, it is increasingly difficult and complex to investigate the discursive uses of cultural heritage under the standard city model, provided there is no standardization. Instead of grossly causing destruction through homogenization, there is a sophisticated appropriation and subjugation of the ICH's contending power in favor of certain interests, which ultimately cause a depreciation of this category.

Continuing with João Domingues ${ }^{59}$ analysis on the impact of urban entrepreneurship on the cultural policies of Rio de Janeiro, three aspects stand out:

i. the uncritical incorporation of the creative economy as a categorical favorite, in which urbanism in Rio de Janeiro makes the city cool, a competitor for capital funds and creative subjects or interested in its innovative aesthetics;

ii. the images derived from this process, based on innovative rites, that promote interventions in the urban layer, which privilege aesthetic forms and the presence of the solvent users of the urban entrepreneurial process;

iii. the current institutional patrimony restriction, which emphasizes the dimension of a landscape fraction of the city instead of expanding on consulting mechanisms for commodification, establishes bureaucratic centralism limits that privilege the material dimensions of patrimonial and heritage policies.

Regarding the third item above, which emphasizes

59 DOMINGUES, João Luiz Pereira. A história institucional recente da política de patrimônio cultural na cidade do Rio de Janeiro: versões protecionistas, versões empreendedoras. Antíteses, v. 9, n. 17, p. 222-245, jan./jun. 2016. p. 242. bureaucratic centralism ${ }^{60}$ and the material dimension of local heritage policies, it is possible to state that the recognition of the intangible dimension of heritage in the cultural policy of the city of Rio de Janeiro was initially included in 2013. This movement is evident in several Brazilian cities.

Concerning the local heritage preservation scenario, especially regarding the rise of ICH in municipalities, Daniel Reis ${ }^{61}$ states that:

In a city one can observe the rapid growth of cultural
heritage departments and commissions governed
by their own legislation, although most of them
have been inspired, to a greater or lesser extent,
by IPHAN's Decree no. 25. However, it is still
interesting to note how quickly they incorporated
the intangible heritage category into their discourses.
Cultural heritage seems to have conquered in the
country a space that was unimaginable a few years
ago in the organization chart of the municipal public
administration. The profile of the institutions varies
in terms of performance, political strength, work
methodologies, professional profiles and heritage
projects.

Nevertheless, considering Rio de Janeiro's case, there is no rupture from the remnants of the modern notion of patrimony and heritage or with the urban entrepreneurship openly discussed by Domingues ${ }^{62}$, releasing, in turn, the contending force of the ICH category. Quite the contrary: the recognition of traditional and notable economic activities (which is present in the second phase previously mentioned, i.e. the entrepreneurial version) determines that the power of the ICH was properly framed by the standard city logic and revisited by urban entrepreneurship.

This novelty brought about by the application of the ICH in cities, moreover, is well demonstrated in the work "Cidade (i)material: museografias do patrimônio cultural no espaço urbano", published in 2015, as a result of the

${ }^{60}$ According to Domingues' theory, the lack of participation and bureaucratic centralism can be considered the origin of the concept gabinetagem, developed by this author and which represents the modus operandi of how certain cultural goods are officially recognized as carioca cultural heritage, meaning without technical studies, without the participation of the people or of the council responsible for heritage in the municipality. They are simply established by a unilateral act of the mayor, which Domingues denominates as gabinetagem.".

61 REIS, Daniel. Cidade (i)material: museografias do patrimônio cultural no espaço urbano. Rio de Janeiro: Mauad X; FAPERJ, 2015. p. 250.

62 DOMINGUES, João Luiz Pereira. A história institucional recente da política de patrimônio cultural na cidade do Rio de Janeiro: versões protecionistas, versões empreendedoras. Antíteses, v. 9, n. 17, p. 222-245, jan./jun. 2016. 
doctoral work of Daniel Reis ${ }^{63}$. The author created a 'museography of urban space' under the influence of Urban Anthropology.

When analyzing the local heritage policy of Juiz de Fora (MG), Reis ${ }^{64}$, in order to prove his hypothesis that the new heritage policies in the cities, especially with respect to intangible assets, reverse the logic that considers heritage as out of market range, he points out:

\footnotetext{
By including intangible heritage as a category there was a minor change in the classic opposition between patrimonial assets and market. The assets correspond, in their majority, to the calendar of events that attract a greater tourist flow to a city that has been seeking to establish itself in this sector. Thus, the intangible assets of the city are also those that attract considerable capital flow, positively affecting the hotel chain, restaurants and other services.
}

Accordingly, as forewarned by Reis ${ }^{65}$, in Rio de Janeiro and in other Brazilian cities, there is an incessant dispute over the implementation of the ICH: on the one hand, the existence of a movement which strives to establish cultural heritage, that neutralizes the contending power of the ICH concept in favor of a standardized and entrepreneurial logic. On the other hand, the strengthening movement of historically inferior individuals and communities who perceive in the ICH an opportunity for providing visibility and strengthening their struggles.

In this tug of war, the heritage category, especially from its intangible approach, becomes "an important tool for when thinking about a city (and cities in general), for it mirrors yearnings, clashes and contradictions as well as specifies the different groups that act in the construction of urban space". ${ }^{66}$

\footnotetext{
63 REIS, Daniel. Cidade (i)material: museografias do patrimônio cultural no espaço urbano. Rio de Janeiro: Mauad X; FAPERJ, 2015.

64 REIS, Daniel. Cidade (i)material: museografias do patrimônio cultural no espaço urbano. Rio de Janeiro: Mauad X; FAPERJ, 2015. p. 251-252.

65 REIS, Daniel. Cidade (i)material: museografias do patrimônio cultural no espaço urbano. Rio de Janeiro: Mauad X; FAPERJ, 2015.

66 REIS, Daniel. Cidade (i)material: museografias do patrimônio cultural no espaço urbano. Rio de Janeiro: Mauad X; FAPERJ, 2015. p. 250.
}

\section{The neutralization of the contending power of the Carioca $\mathrm{ICH}$ and the erasure process of collective memory}

From the standard city and urban entrepreneurship context, a recognition policy of intangible assets emerges in Rio de Janeiro. Contrary to the state of Rio de Janeiro, which is guided by the apparent absence of policies (i.e. it has specific legislation, but has no strategy to implement the normative precepts referring to intangible cultural heritage at the state level), it was verified that the municipality has sought to implement the precepts of the norms referring to the Carioca ICH.

The establishment of the Traditional and Notable Economic Activities (AETN) category is, therefore, an important milestone, since it was considered the first time that strategies for a local cultural policy for $\mathrm{ICH}$ were outlined, overcoming the series of random and casuistic declarations that previously prevailed.

The recognition of Traditional and Notable Economic Activities can be understood through three phases, all of which correspond to the publication of three municipal decrees. The phases can be described as follows:

\begin{abstract}
i. The emergence, as a result from disputes concerning Rua da Carioca, (Carioca Street) an important commercial point situated in Downtown Rio de Janeiro which can be designated as the starting point for AETN. This phase is marked by the clash that began between the Sociedade Amigos da Rua da Carioca or Friends Society of Rua da Carioca (SARCA) and the Opportunity Group, owner of most of the properties where the AETN of Rua da Carioca are established $^{67}$;

ii. The expansion or the foreshadowing of the expansion of this cultural policy beyond Rua da Carioca through the creation of a Registry for Traditional Businesses ${ }^{68}$;
\end{abstract}

\footnotetext{
67 In this first phase, through Decree no. 37.273/2013, nine assets of an intangible nature were registered in the newly created Record Book of Traditional and Notable Economic Activities (AETN): I - Carioca Street, 7. Casa Nova Zurita (King of Knives) - Cutlery trade; II - Carioca Street, 15. Irmãos Castro - Hardware and household items; III - Carioca Street, 17. Mala de Ouro - Trade in handbags and suitcases; IV - Carioca Street, 19. Mariu's Sport - Sports equipment; V - Carioca Street, 21. Padaria e Confeitaria Nova Carioca - Bakery and confectionery; VI - Carioca Street, 20 and 22. Ponto Masculino - Trade in high end men's clothing; VII - Carioca Street, 35. Vesívio - Sale of weather protection equipment; VIII - Carioca Street, 37. A Guitarra de prata - Sale of musical instruments; IX - Carioca Street, 39. Bar Luiz - Bar and restaurant. 68 In this second phase, through Decree no. 39.705/2014, the fol-
} 
iii. The Valuable Businesses, evidenced by the creation and influence of a new protagonist, the Support Service for Micro and Small Companies of Rio de Janeiro (SEBRAE/RJ), which implemented the project denominated as 'Valuable Businesses' operating directly with the activities that were selected and registered as AETN by the IRPH ${ }^{69}$.

These phases, however, will not be further analyzed, but it is important to recognize that there has been a significant change in the direction of local cultural policies: from the so-called rhetoric of loss to urban entrepreneurship. This trend was accompanied by a territorial expansion of the policy that recognizes AETNs, widening the spectrum of Rua da Carioca (Carioca Street) to other territories, without exceeding, as can be seen in the polygon traced below, the limits of the Downtown region of Rio de Janeiro.

lowing assets were registered: "Article $2^{\circ}$. The establishments listed below are registered in the Register of Traditional and Notable Businesses: a. Bandolim de Ouro - Marechal Floriano Avenue, 120 Downtown; b. Chapelaria A Esmeralda - Marechal Floriano Avenue, 32 - Downtown; c. Chapelaria Alberto - Buenos Aires Street, 73 Downtown; d. Chapelaria Porto - Senador Pompeu Street, 94, Sobrado - Downtown; e. Charutaria Syria - Senhor dos Passos Street,180 Downtown; f. Cofres Americanos - Teófiio Otoni Street, 120 - Downtown; g. Cofres Gaglianone - Teófiio Otoni Street, 134 - Downtown; h. Confeitaria e Restaurante Cirandinha - Nossa Senhora de Copacabana Street, 719 - Copacabana; i. Confeitaria La Marquise - Carvalho de Mendonça Street, 29 - Copacabana; j. Gráfica Marly - Livramento Street, 40 - Downtown; k. Leiteria Mineira - Ajuda Street, 35, store A - Downtown; 1. Livraria Padrão - Miguel Couto Street, 40 - Downtown and; m. Tabacaria Africana - Praça XV."

69 According to Decree no. 43.914/2017, "Article 1 The following cultural assets are registered as Intangible Cultural Heritage [...]:I - A Mala Ingleza, Marechal Floriano Avenue, $n^{\circ}$ 81, Downtown; II - A Roseira da Cruz Vermelha, Praça da Cruz Vermelha, $n^{\circ}$ 40, Downtown; III - Angu do Gomes, Largo de São Francisco da Prainha, no 3, Saúde; IV - Bar Brasil, Mem de Sá Avenue, no 90 , Downtown; V - Caça e Pesca, Marechal Floriano Avenue, $\mathrm{n}^{\circ}$ 83, Downtown; VI - Café do Bom Cachaça da Boa, Carioca Street, $\mathrm{n}^{\circ}$ 10, Downtown; VII - Carioca da Gema, Mem de Sá Avenue, no 79, Downtown; VIII - Casa Azevedo, Senhor dos Passos Street, $n^{\circ} 63$, Downtown; IX - Casa Urich, São Jose Street, $n^{\circ}$ 50, Downtown; X - Cedro do Líbano, Senhor dos Passos Street, no 180, Downtown; XI - Chapelaria Alberto, Buenos Aires Street, $n^{\circ} 73$, Downtown; XII - Charutaria Syria, Senhor dos Passos Street, no 180, Downtown; XIII - Confeitaria Carolana, Buenos Aires Street, $n^{\circ} 124$, Downtown; XIV - Confeitaria Colombo, Rua Gonçalves Dias, n ${ }^{\circ}$ 32, Downtown; XV - Gráfica Marly, Livramento Street, no 40, Gamboa; XVI - Jaqueta Ideal, Camerino Street, $n^{\circ} 70$, Downtown; XVII - O Veleiro, Teófilo Otoni Street, no 48, Downtown; XVIII - Olegário e Lourenço. Regente Feijó Street, $\mathrm{n}^{\circ}$ 12, Downtown; XIX - Rio Scenarium, Lavradio Street, $n^{\circ} 15$, Downtown; XX - Salão OK, Senador Dantas Street, $n^{\circ}$ 24, Store D, Downtown; XXI - Salão Pop, Gonçalves Ledo Street, $\mathrm{n}^{\circ}$ 7, Downtown; XXII - Tabacaria Africana, Praça Quinze de Novembro, n 38, Downtown; XXIII - Vidromar, Senado Street, no 166, Downtown.".
Figure 1 - Territorial span of the three Municipal Decrees for the recognition policy of AETNs

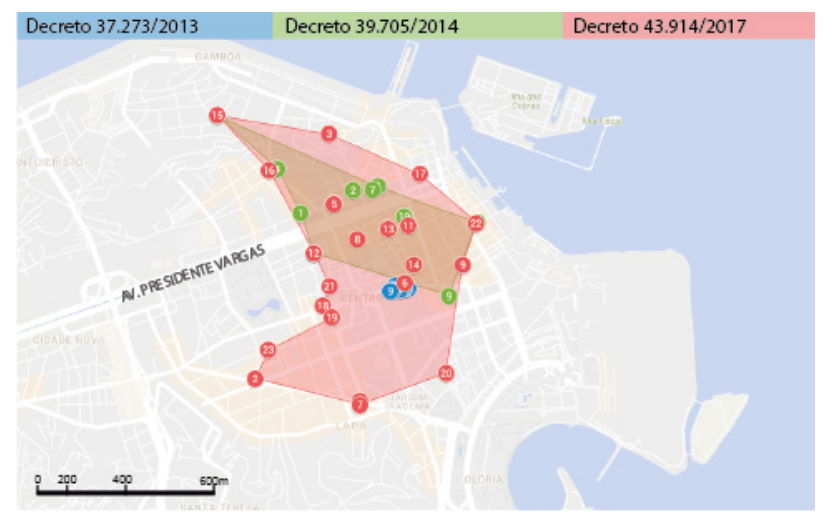

Nevertheless, notwithstanding the attribution of value that recognizes them as cultural heritage, these cultural assets are essentially private economic activities and, therefore, are susceptible to the market logic.

Thus, it is worth repeating that in patrimonizalization processes or in processes which focus solely on assets, the know-how or knowledge involved in the trade are not acknowledged, favoring instead the economic activities themselves as intangible cultural heritage. In this context, the intangible cultural heritage category (ICH) is appealed to several times in order to provide longevity to these economic activities, either through the well-known permanence tactic or, as occurs in Rio de Janeiro, through the sophisticated logic of urban entrepreneurship ${ }^{70}$ driven by the dictates of the standard city $^{71}$.

The anthropologist Antônio Augusto Arantes ${ }^{72}$ cautions that in order to analyze a case concerning heritage, notably in a complex urban context such as Rio de Janeiro, it would be appropriate to use the ethnographic method to distinguish some points that are hidden in cartographies, dichotomous schemas (downtown/periphery, tangible/intangible, public/private) and, especially in normative elaborations on the subject, since the patrimonizalization processes are fluid, ambiguous and

70 Cf. DOMINGUES, João Luiz Pereira. A história institucional recente da política de patrimônio cultural na cidade do Rio de Janeiro: versões protecionistas, versões empreendedoras. Antiteses, v. 9 , n. 17, p. 222-245, jan./jun. 2016.; Cf. HARVEY, David. A produção capitalista do espaço. São Paulo: Annablus, 2006.

71 CAVALLAZZI, Rosângela Lunaderlli. Cidade Standard: desafios da paisagem em movimento. In: AHMED, Flávio; SOARES, Inês Virgínia Prado (org.). Bens culturais e cidades sustentáveis. Rio de Janeiro: Lumen Juris, 2016.

72 ARANTES, Antônio Augusto (org.). O espaço da diferença. Campinas: Papirus, 2000.; ARANTES, Antônio Augusto. A guerra dos lugares: sobre fronteiras simbólicas e liminaridades no espaço urbano. Revista do Patrimônio Históricos e Artístico Nacional, Brasília, n. 23, 1994. 
the actors involved are in constant transit.

In other words, analyzing the heritage institutional policies in Rio de Janeiro and the respective normative elucidations wouldn't be enough to comprehend the existing complex relations. Therefore, it is necessary to apply an 'ethnographic attitude"73, without forgetting the 'anthropological blues ${ }^{74}{ }^{75}$, in order to understand the granular dimension ${ }^{76}$ of the producers/stakeholders of intangible assets, and acknowledge the rejection of the policies and legal protection granted to ICH in territories where they transit and negotiate their survival.

At this point, the present article mentions once again the reference case of Chapelaria Porto, which will be further analyzed in section three. Chapelaria Porto was one of the thirteen establishments selected in the $\mathrm{Mu}$ nicipal Decree no. 39.705/2014, a statute part of the triad of decrees for recognizing traditional and notable economic activities.

Based on technical visits and interviews with the owner of the referred establishment, the first having occurred in $2016^{77}$ and the second in $2017^{78}$, it is possible to appreciate how the policy and local legal protection

73 In this article, one does not intend to undertake an ethnography, but through an interdisciplinary approach, propose an intense dialogue with other fields of knowledge, especially that of Anthropology and their respective methodologies. João Domingues, responsible for coining this concept is of great importance and influence, for by doing so, barriers created between the fields of Law and Anthropology are greatly reduced.

${ }^{74}$ DAMATTA, Roberto. O ofício do etnólogo ou como ter anthropological blues. Boletim do Museu Nacional, n. 27, 1978.

75 In the classic 1978 article by author Roberto Damatta, he writes about the work of an ethnologist and the essential "anthropological blue", necessary for the discovery of the interpretive aspects of this craft, especially those that can be considered "non-scientific", extraordinary, and that emerge from the human feeling and which must be incorporated into ethnography.

76 GUELMAN, Leonardo Caravana. A experiência múltipla de um projeto e seus enraizamentos no território. In: GUELMAN, Leonardo C.; SANTOS, Juliana Amaral dos; GRADELLA, Pedro de Andrea (orgs.). Prospeç̧ão e capacitação em Territórios Criativos: desenvolvimento de potenciais comunitários a partir das práticas culturais nos territórios Cariri (CE), Madureira, Quilombo Machadinha e Paraty (RJ). Niterói: CEART; Mundos das Ideias, 2017.

${ }_{77}$ The first interview was held on 20 April, 2016. Interviewee: Vanusa Damaso - Owner. Interviewers: Mário Pragmácio and Júlia Fraga. Location: Chapelaria Porto Shop - Senador Pompeu Street, 94, Sobreloja.

78 The second interview, held on 19 April, 2017, is a secondary source. Interviewee: Vanusa Damaso - Owner. Interviewers: João Domingues, Kyoma Oliveira, Julia Fraga, and Matheus Saudino. Location: Chapelaria Porto Shop - Presidente Vargas Avenue, 446, Room 1703. of the ICH operates, now seen on a scale that privileges the perspective of the producers/stakeholders of intangible assets.

This approach aims at evidencing not only the appropriation of the ICH but also the neutralization of the central element of this category: its contending force.

Hence, the following question must be addressed: what are the dynamics of the ICH, especially that of the Traditional and Notable Economic Activities, in Downtown Rio de Janeiro during the Paes Government, and what are the consequences to policy and the protection pertaining to ICH at a municipal level?

In $2013^{79}$, with the creation of the new AETN Record Book, for the first time within the municipality of Rio de Janeiro, the initiative for the elaboration of a cultural policy focused on the ICH was developed. There was a continuity to the actions taken, a standardization of safeguard guidelines and the participation of other actors, including that of the Mayor in the design and institutional arrangements. As much as there is criticism about this process, it is undoubtedly a milestone for the local heritage policy.

Prior to this occurrence, from an institutional point of view, the ICH of Rio de Janeiro was used in a random and un-specified manner, and could even be understood as the object of an "undue" appropriation, condemned as such in the II Fortaleza Charter ${ }^{80}$ through populist declarations, but lacking any technical support. These declarations are here on after referred to as gabinetagem $^{81}$.

The term gabinetagem, in rephrasing Albino Rubim's description ${ }^{82}$, is a sad tradition inherited from local preservation actions that authoritatively concentrated the

79 The Record Book and the Register are Brazilian legal instruments, created in 2000, which aim at preserving and safeguarding the ICH. The register occurs through the Registration in one of the Record Books.

80 The new version of the Fortaleza Charter, written in 2017, warns that there is a recurrent "misunderstanding of the notion of intangible heritage and its safeguard, which leads to misappropriations of a purely populist nature where the complexity of this process is utterly ignored.".

81 DOMINGUES, João Luiz Pereira. A história institucional recente da política de patrimônio cultural na cidade do Rio de Janeiro: versões protecionistas, versões empreendedoras. Antíteses, v. 9, n. 17, p. 222-245, jan./jun. 2016.

82 RUBIM, Antônio Albino Canelas; BARBALHO, Alexandre (orgs.). Politicas culturais no Brasil. Salvador: EDUFBA, 2007. 
attribution of value to cultural assets in a technocratic and unilateral way, as an exclusive act of the head of the municipal executive power. Therefore, this process of isolated patrimonizalization allows for the Mayor to chose when to trigger this category solely according to his own demands, needs, and/or priorities.

From a legal point of view, this results in serious distortions which, considering the creation of the registration process in 2013, have already become the preservationist policy of the municipality of Rio de Janeiro's main focus. To name a few, these are typical examples of gabinetagem that occurred during the last three governments ${ }^{83}$ : the declaration of Flamengo's fan club, which is one of Brazil's biggest football teams ${ }^{84}$, as ICH; the goals scored by football player Zico, in the Maracanã Stadium ${ }^{85}$; and recently, the classification of the regular yellow and blue taxis in Rio de Janeiro as $\mathrm{ICH}^{86}$.

The described practice of gabinetagem not only discredits the actions and respective instruments for preserving intangible cultural heritage, but also excludes the community, mainly the stakeholders and producers from the process of patrimonizalization of the intangible assets. Public participation must be carefully observed, especially considering the established by articles $216^{87}$ and $216-\mathrm{A}^{88}$ of the 1988 Brazilian Federal Constitution, combined with article 15 of the 2003 Convention for the Safeguard of Intangible Cultural Heritage ${ }^{89}$.

However, the reference case of the AETN alters the pattern established by the previous gabinetagem acts.

83 Not to mention the use of the ICH by the legislative power, such as the "carioca accent", declared as a Carioca ICH, by Law No. 5.982/2015.

84 Determined by Mayor César Maia (1993-1997; 2001-2008), through Municipal Decree no. 28.787/2007.

85 Determined by Mayor Eduardo Paes (2009-2016), through Municipal Decree no. 37.234/2013.

86 Determined by Mayor Marcelo Crivella (2011-), through Municipal Decree no. 43.256/2017.

87 "The public power, with the collaboration of the community $[\cdots] "$.

${ }_{88}$ Article 216-A concerns the National Cultural System (SNC), from which the hypothetical National Cultural Heritage System (SNPC) derives, bringing various devices that encourage popular participation, such as the SNC principle foreseen in item "X - democratization of decision-making processes with social participation and control.".

89 "Article 15 (Participation of communities, groups and individuals): Within the framework of their activities to safeguard intangible cultural heritage, each State Party shall ensure the amplest participation of communities, groups and, where appropriate, individuals who create, maintain and transmit this heritage and actively associate them to its management.".
Thus, there is finally a change, an inflection of perspective in the patrimonizalization process.

Evidently, the municipality of Rio de Janeiro has been attempting to establish a local cultural policy, as proposed by Canclini ${ }^{90}(2005)^{91}$. In spite of recognizing that there was an effort to interrupt the deleterious cycles of gabinetagem ${ }^{92}$, there is, primarily in relation to the third objective of the Canclinian definition (2005) of cultural policy ${ }^{93}$, a point of divergence with the hypotheses addressed in this article.

In other words, although there was the structuring of a pioneering cultural policy at the municipal level, the strategic planning that guided this policy, effectively speaking, failed to reach the promised discourse of a social transformation. Quite the opposite. There was the ratification of the urban-cultural order, through the compliant use of the $\mathrm{ICH}$, which is contrary to the precepts established by the intangible cultural heritage category.

What are the consequences of using ICH in this context? The following question is again insisted upon: what can be extracted from the fact that several economic activities were recognized as intangible cultural heritage in the Downtown area of Rio de Janeiro during the Paes Government?

As formerly mentioned, the cultural policy of the AETN, within the proposed time and territorial framework, was regulated by urban entrepreneurship under the influence of the standard city imperatives.

A standard city, as was analyzed beforehand, frames and packages the city's cultural heritage, whether tangible or intangible. It discards, ruins or discourages

90 CANCLINI, Néstor Garcia. O patrimônio cultural e a construção imaginária do nacional. Revista do Patrimônio Histórico e Artístico Nacional, n. 23, p. 95-115, 1994.

91 Canclini defines cultural policies as a set of interventions carried out by the State (commissive element), in order to achieve three objectives, and the third can be chosen between two options, namely: guide the symbolic development (objective 1), meet the cultural needs of the population (objective 2), and to establish a consensus for a type of urban-cultural order (objective 3 ) or to generate a social transformation (counter objective to objective 3).

92 The act of gabinetagem has not been extinguished and still persists at the municipal level. An example: the inclusion of yellow taxis as part of the intangible cultural heritage, determined during the Crivella Government, through Municipal Decree no. 43.256/2017.

93 In the Canclinian definition (2005), the Carioca's cultural policy sought to establish a consensus for a type of urban-cultural order (objective 3), instead of operating a social transformation (counter objective to objective 3 ). 
everything that is considered undesirable to the precepts of standardization. Conflicts and clashes, which are part of the heritage field, are made void and forgotten in a standard city, for in such a context, cultural heritage is only used aseptically, thus conveying the notion of consensus and cordiality.

The ICH category is, therefore, appropriated by the entrepreneurial logic, for it has potential for being claimed by the historically and traditionally vulnerable and inferior individuals and/ or social groups so as to provide them with greater visibility. Urban entrepreneurship incorporates intangible cultural heritage as something profitable and which contributes to the strengthening of a city brand, thus distinguishing Rio de Janeiro in the competitive global market of cities, particularly when it was hosting major events in 2014 and 2016.

This article addresses the consequences of applying the ICH category in the described terms, which may ultimately cause the neutralization of this category's contending power, therefore triggering, in a medium-to-long term, an erasure process concerning certain individuals and social groups. In this context, the following questions are raised: What is meant by erasure? How does it transpire? What and who does it concern?

\section{The reference case of Chapelaria Porto}

Considering preservationist policy as an act of memory, erasure would be the exact opposite, that is, a process of oblivion, of ultimately forgetting. As opposed to the official documents, the recognition of certain AETN within this entrepreneurial and standardizing logic causes a side effect, which distorts the historical configuration of this category, especially when it comes to the transforming potential attributed to such category.

This kind of reasoning leads to the permanent damage of ICH's central element, that is, its contending potential, as a result of the friction imposed on the modern notion of heritage ${ }^{94}$. When this process is analyzed in a granular scale ${ }^{95}$, which is smaller and to a certain ex-

\footnotetext{
94 CHOAY, Françoise. A alegoria do patrimônio. São Paulo: Estação Liberdade; UNESP, 2006.

95 GUELMAN, Leonardo Caravana. A experiência múltipla de um projeto e seus enraizamentos no território. In: GUELMAN, Leon-
}

tent more precise in comparison to the normative-institutional scale, this loss of power and impact is clearly perceived, specifically considering the existence of different influxes and disputes involving ICH stakeholders and producers.

The Chapelaria Porto case is emblematic in demonstrating this hypothesis, since it suffered the consequences of the appropriation and the neutralization of the $\mathrm{ICH}$, thus experiencing in fully blown proportions the described process of erasure.

Chapelaria Porto was one of thirteen establishments registered in the official Registry created by the Municipal Decree no. 39.705/2014. However, this particular Chapelaria (or establishment), although initially selected, did not make it to the final list of those chosen by SEBRAE-RJ's Valuable Businesses project, and was therefore excluded from the Registry for cultural assets of an intangible nature as referred in the Municipal Decree no. 43.914/2017. This exclusion, comprehended as an act of invisibility and oversight, was not merely procedural, but part of the process of erasure previously described.

Inaugurated in 1880, Chapelaria Porto was located on Senador Pompeu Street, Downtown Rio. Although it changed addresses a few times, it was always located Downtown, near the Port Area of Rio de Janeiro. As a Chapelaria, it not only sells but also makes tailored hats, which is evidence of a know-how linked business. Already in its fourth generation, proving historic continuity as well as the transfer of such a know-how in between generations of the same family, it was also acknowledged by the Rio Institute of Humanity Heritage as a tradition ${ }^{96}$.

The current owner of Chapelaria Porto, Vanusa Damaso, interviewed in $2016^{97}$, explained that she follows a family tradition of making hats, which comes from her great-grandfather and great-great-uncle, "when

ardo C.; SANTOS, Juliana Amaral dos; GRADELLA, Pedro de Andrea (orgs.). Prospeç̧ão e capacitação em Territórios Criativos: desenvolvimento de potenciais comunitários a partir das práticas culturais nos territórios Cariri (CE), Madureira, Quilombo Machadinha e Paraty (RJ). Niterói: CEART; Mundos das Ideias, 2017.

96 Article 1 of Resolution 02/2016 of the IRPH lists the essential elements needed for the recognition of AETN, among them: [...] II. Tradition: commerce transmitted between generations. [...].

${ }^{97}$ Interviewee: Vanusa - Owner. Interviewers: Mário Pragmácio and Júlia Fraga. Date: 20 April, 2016 Location: Chapelaria Porto Shop - Senador Pompeu Street, 94, Sobreloja. 
they started the establishment, it was on this very same street, in that corner, on the corner of Camerino Street with Senador Pompeu Street". Later, it was then passed on to her grandfather, and later to her father, Almir: "I am the only woman. I am the fourth generation, the only woman who works in this type of commerce in Rio de Janeiro", says Vanusa ${ }^{98}$.

Almir, Vanusa's father, is currently retired. Vanusa, the fourth generation of the family, took over the leadership of the Chapelaria, regardless of the prejudice she knew existed. The gender issue is present in Vanusa's testimony, since the know-how linked to the Chapelaria business has historically been a male trade, and store customers are mostly men ${ }^{99}$.

The uniqueness of Chapelaria Porto, in relation to the other headgear establishments ${ }^{100}$, is proven precisely by the hat-making know-how, passed on for four generations, thus making it unique:

\begin{abstract}
In a hat shop, you are a chapeleiro, a hatter because you are the one to create the hat. We customize hats, we are the only Chapelaria that does it all, the other shops, that came from generation to generation, only sell hats. Not me, I continued with tradition because I have the gift of art, so I am the only hatter in Rio de Janeiro. We are able to make any hat style, modeling and tailoring it as per customer, all of which is done under an hour. ${ }^{101}$
\end{abstract}

When questioned about the "perpetuation"102 of the business and know-how, Vanusa replied that "for the time being I have not yet found the person. But I'm waiting on God. We wait on God because not even I

98 Interviewee: Vanusa - Owner. Interviewers: Mário Pragmácio and Júlia Fraga. Date: 20 April, 2016 Location: Chapelaria Porto Shop - Senador Pompeu Street, 94, Sobreloja.

99 As reported by Vanusa, there are women clients too, "for the Globo network, for the soap operas, for the big prize, understand? But everything is down. [...]. The women came here, at the time they sat with my father, and at my father's side, and telling him what and how they wanted their customized hats and he would listen and create the desired product... he would customize the hats as requested. [...]”. Interviewee: Vanusa - Owner. Interviewers: Mário Pragmácio and Júlia Fraga. Date: 20 April, 2016 Location: Chapelaria Porto Shop - Senador Pompeu Street, 94, Sobreloja.

100 In the same Decree that determined the inclusion of Chapelaria Porto in the Register, there are two other Chapelarias that were recognized as meeting the requirements: Chapelaria Alberto and Chapelaria Esmeralda.

101 Interviewee: Vanusa - Owner. Interviewers: Mário Pragmácio and Júlia Fraga. Date: 20 April, 2016 Location: Chapelaria Porto Shop - Senador Pompeu Street, 94, Sobreloja.

102 Recurrent neologism in Vanusa's discourse to refer to the historical continuity and intergenerational transfer of intangible nature goods/assets. believed I'd be here. Can you understand this? I never imagined being a chapeleira"103. She further explains:

People are only amazed, they think that a woman chapeleiro is cool, they even joke about the mad hatter with me [...] But I have the greatest pride in maintaining a store [...] Since 1880, it has been a great burden. When I became part of the business, I really understood the history involved, something I had never imagined or really thought about [...] When I was little, I would go to the store to be with my grandfather and to tease him, win a hat of my own; when I grew up, my father would gift me with hats, did you understand? And suddenly, my father falls ill and I assume. So, I provided "perpetuation", and my father still asked, "Do you want to pass the business back to me?" I said, no father, I want to continue. I want to perpetuate this story. I like it and will do so with pride $[\ldots]^{104}$

Once the habit of wearing hats practically disappeared in the great contemporary cities, Chapelaria Porto depended mainly on specific orders, during specific seasons and festive dates such as Carnaval. Vanusa explained that she currently works with customization of hats, highlighting two types of customers: Samba Schools and Entities.

It is worth remembering that the Samba Matrix of Rio de Janeiro, among them the Samba-Enredo ${ }^{105}$ (which is the samba music composed for the Carnaval parade and which tells a story), are part of the intangible assets registered at a federal ${ }^{106}$ level, which confirms the connection between trade traditionally carried on by the chapelarias (hat shops), with referred to assets considered as Brazilian cultural heritage, intimately connected to the Samba Schools.

The Entities to which Vanusa refers to are spiritual manifestations of Afro-Brazilian religions. Vanusa relates that many of these Entities order handmade, artisanal hats, all of which are made by Chapelaria Porto: "Exactly. We are the ones who craft them. Not only

103 Interviewee: Vanusa - Owner. Interviewers: Mário Pragmácio and Júlia Fraga. Date: 20 April, 2016 Location: Chapelaria Porto Shop - Senador Pompeu Street, 94, Sobreloja.

104 Interviewee: Vanusa - Owner. Interviewers: Mário Pragmácio and Júlia Fraga. Date: 20 April, 2016 Location: Chapelaria Porto Shop - Senador Pompeu Street, 94, Sobreloja.

105 The other matrices are: Partido Alto and Samba de Terreiro. They are means of expression, ways of socializing and of belonging. They are also relevant cultural references in the panorama of music produced in Brazil.

106 The Samba-Enredo was also declared an intangible cultural heritage of Rio de Janeiro by an act of the so-called gabinetagem, according to Municipal Decree no. 42.708/2016. There is no obstacle for the overlapping records/registers between the federal entities. 
for samba schools [...] there are also these religions that come here for hats, the entities, as well as other people who visit Downtown Rio. [...] Candomblé, Umbanda $[\ldots] "{ }^{107}$

This type of commission is considered ancestral. Vanusa explains that tailor-made, handcrafted hats for such users, for Entities, is something that comes from her grandfather's time:

Oh, since my grandfather's time. Wow [...] The malandragem (rascality), since that time, understand? And later on, when the samba schools started too [...] These are people from "the talk of the town", that's how people refer to them. Those who are from entities, that kind of thing, and who came looking for us, because that's how I tell you, we customize the hat, so [...] The entity wants a hat with a yellow ribbon. You will not find the yellow ribbon. But here, you can. There was an entity that wanted a braided ribbon. Nobody knew how to find this. Anyway [...] I just knew what it was like. I had that intuition of knowing what it was like. ${ }^{108}$

Chapelaria Porto, selected by the Registry Decree, was not included in the final list of those contemplated by the SEBRAE-RJ'S Valuable Businesses project, nor was it registered in the AETN Record Book, even though it satisfied all the necessary requirements, according to Article 1, IRPH's no. Resolution 02/2016. ${ }^{109}$

Accepting the responsibility, Vanusa confesses that she could not attend the meetings promoted by SEBRAE-RJ, because she could not leave the store unattended to ${ }^{110}$. Participation in these meetings was an indispensable condition to proceed with the Valuable Businesses Project and, consequently, be registered as an ICH. At that time, Vanusa worked in very precarious conditions, living inside the store. She worked other jobs, such as seamstress and as a commercial representative for a clothing brand, in order to maintain

\footnotetext{
107 Interviewee: Vanusa - Owner. Interviewers: Mário Pragmácio and Júlia Fraga. Date: 20 April, 2016 Location: Chapelaria Porto Shop - Senador Pompeu Street, 94, Sobreloja.

108 Interviewee: Vanusa Damaso - Owner. Interviewers: João Domingues, Kyoma Oliveira, Júlia Fraga e Matheus Saudino. Date: 19 April, 2016 Location: Chapelaria Porto Shop - Presidente Vargas Avenue, 446, Room 1703.

109 Namely: I. Production process/traded item: a business that preserves knowledge, techniques and/or traded items considered traditional; II. Tradition: commerce transmitted between generations; III. Reputation: trade recognized by residents and visitors of the region as a symbol of the territory; IV. Brand value: recognition of the traditional brand; V. Ancestry: length of stay in the territory.

${ }_{110}$ As if the store were a person, someone who is part of the family to whom Vanusa owed attention to and should acre for.
}

the Chapelaria. Regarding the project's participation in partnership with SEBRAE, Vanusa explains:

Yes, we did participate. And then, it was really my fault, I will not deny it. Because I was in this [situation] [...] An economic crisis began, I was torn between the store and the meetings and I ended up losing. They didn't consider me because I lacked in presence, and I do not disagree with them. It seemed like it was a lack of interest, but it was not. I was torn up between the store and SEBRAE, and I know SEBRAE was going to help me too, but the timing was off. And the crisis was worse each day that I would either have to attend, or close the doors the shop, I had to choose one of two things. Although the meeting was always at 4:00 pm, I always arrived late, especially because at times I worked in three places, and slept in the store. I made a house here in the store in order to compensate. So, these were my conditions: $\mathrm{Me}$, as a shop, in order to survive, understand? I lost despite of this, and I was very sorry, and I did not have the courage to ask my father to go, either. Everything depended on me, I was starting to manage the store as well, so I was really sad to have lost the opportunity. I would like, in the future if I had the opportunity again, to really grab it and get a second chance. But I would like it in a period that I was already in a good, stable situation to take it seriously. I did take it seriously the first time, only the conditions were unfavorable, I was supporting a job in order to make money and pay rent and water access and other basic needs. If I couldn't pay for them any longer, what was going to happen? I would have to close the shop. ${ }^{111}$

Therefore, Chapelaria Porto was removed from the SEBRAE-RJ's Valuable Businesses Project and from the AETN Record Book. The official explanation, confirmed in the excerpt from the interview transcribed above, is that Vanusa was not assiduously present at the meetings.

However, these events are worth analyzing from a political-institutional conjuncture, thus including the recognition of the AETNs as ICH. Vanusa was the only one responsible for the store, and the meetings were held during business hours, which meant that there was obviously no way for her to attend them.

The conditions in which Vanusa exercised her trade were not only poor and unstable ${ }^{112}$, but placed her in a vulnerable situation. It is worth mentioning that she was

\footnotetext{
111 Interviewee: Vanusa - Owner. Interviewers: Mário Pragmácio and Júlia Fraga. Date: 20 April, 2016 Location: Chapelaria Porto Shop - Senador Pompeu Street, 94, Sobreloja.

112 In an interview, Vanusa opened up about having to live in the shop, when it was originally located on Senador Pompeu Street, in completely unhealthy and unsanitary conditions.
} 
a young woman undertaking a traditionally male trade in a degraded area of the city, with the main clients being representatives of the black culture, such as the Samba Schools of Rio de Janeiro, which drastically reduced the number of requests for costumes due to the financial crisis and the dismantling of the incentive to cultural productions in the state of Rio de Janeiro and in Brazil; and the Spiritual Entities, who sporadically order tailored hats and accessories.

One must then consider the following question: $\mathrm{Cha}$ pelaria Porto, as an asset of intangible nature, a right fit for the model predefined by the urban entrepreneurial logic? To what extent is the visibility of this business, based on the recognition of the trade developed by the chapeleira, in association with the AETNs, compatible with the purposes established by the standard city?

Chapelaria Porto, driven by the financial crisis and by these conditions of invisibility and vulnerability to which it was imposed, changed the address of its headquarters. This had already happened in other moments of the trajectory of such a centenary trade ${ }^{113}$, but it always maintained the characteristics essential to a 'street store', whether in a garage or in a sobrado (loft).

Figure 2 - Territorial span of the three Municipal Decrees for the recognition policy of AETNs, with Chapelaria Porto's displacement (4A-4B)

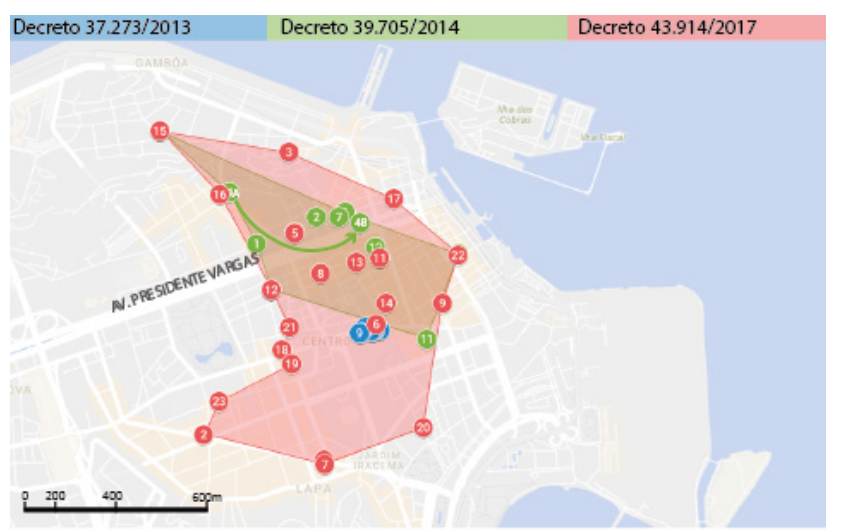

This territorial displacement (from 4A to 4B), despite being within the AETN polygonal, is symptomatic to demonstrate the hypothesis defended in this article, because this time, the displayed shift was crucial. The

\footnotetext{
113 There is a divergence regarding the previous addresses. During one of the interviews, Vanusa, who currently own the Chapelaria Porto, said that the original store was located on Senador Pompeu Street, 34, and that later on, due to a fire, it was transferred to number 114. Until the year 2016, Chapelaria Porto was located and open to business on Senador Pompeu Street, 94, Sobreloja, Downtown Rio, address listed in the Registry Decree.
}

Chapelaria moved from Senador Pompeu Street to the seventeenth floor of a commercial building on Presidente Vargas Avenue ${ }^{114}$, removing, once and for all, what was left of the remaining visibility, that is, for those who walked through the streets of Downtown Rio ${ }^{115}$.

Thus, the erasure process presented in this article are perceived, in the referenced case, in two distinct ways: first, through the removal of Chapelaria Porto from the SEBRAE-RJ's Valuable Businesses Project and, therefore, from the AETN Record Book; secondly, by the location displacement of Chapelaria Porto, from Senador Pompeu Street, to a commercial room in a building located on Presidente Vargas Avenue.

Thus, it is worth recalling an excerpt from the anthropologist José Reginaldo do Santos Gonçalves paper $^{116}$ in which the author demonstrates concern with the trivialization of the heritage category, especially with the "political risks, which consist in the elimination of the force associated to category, as an instrument that is characteristically implemented for attaining public recognition of groups and individuals.".

Chapelaria Porto was included in the Registry for Traditional and Noble Businesses, whose legal and political effects are not clearly defined. It is only a list that, in a very broad and generous interpretation, would bring about an allocation of value, recognizing certain assets as intangible cultural heritage, even if through an intricate and somewhat doubtful method.

The non-registration of Chapelaria Porto in the AETN Record Book, remaining listed solely in the Registry, is a symptom of the erasure process; an omen of oblivion.

One of the purposes of the mentioned registration in the Record Book is to recognize and provide value to assets of an intangible nature. Therefore, those who own assets of intangible nature gain more visibility, leading to other favorable consequences that ultimately

\footnotetext{
114 Presidente Vargas Avenue, 446, Room 1703, Downtown Rio de Janeiro.

115 As already mentioned, several AETNs have already changed their address, which is an expected occurrence. The property where the AETN is situated may or may not be an indispensable condition for the full fruition of cultural heritage. But all recognized AETNs have the common characteristic of being "street located stores". 116 GONÇALVES, José Reginaldo Santos. Os limites do patrimônio. In: LIMA FILHO, Manuel Ferreira; ECKERT, Cornélia; BELTRÃO, Jane (orgs.). Antropologia e patrimônio cultural: diálogos e desafios contemporâneos. Florianópolis: Nova Letra; ABA, 2007. p. 239.
} 
decimate their vulnerability, which often comes from a historical condition of inferiority.

Undoubtedly, the registration of Chapelaria Porto in the AETN Record Book could provide visibility to the craft undertaken by Vanusa, which is currently connected to the cultural manifestations of historically inferior subjects, such as the Afro-Brazilian community ${ }^{117}$. In addition, although the craft of making hats is still regarded as a traditionally male know-how, it cannot be ignored that, in this case, it is and has been exercised, by a woman.

These social groups struggle to break this ongoing and perpetual cycle of invisibility to which they are subjected. The registration would, therefore, be a valuable fighting instrument for this struggle.

Although the reference case of Chapelaria Porto is exemplary, it is still not enough to explain, by means of analogy, the condition of other AETNs recognized as intangible cultural heritage in Rio de Janeiro. Nor could it do so, for it would be necessary to investigate each and every one of them ${ }^{118}$, analyzing the nuances of each cultural asset that compose such a list. However, this article aims at exposing the contradictions of this cultural policy, which, directly or indirectly, annuls existing conflicts in the field of heritage, thus misrepresenting the origin and purposes of the $\mathrm{ICH}$.

Chapeleira Porto fails to expose all of the elements and assets involved in this cultural policy. Quite the opposite. It demonstrates the existence of a "back door", an "escape goat", where certain assets are subtly discarded and excluded due to an entrepreneurial logic, since they do not fit into the defined profile, which prioritizes the recognition and dissemination of intangible cultural assets that do not bear visible evidences of conflicts and clashes.

\footnotetext{
117 It is said "currently" because in a certain period of history, the trade of making hats was connected to other social groups, including the bourgeoisie. This change can be justified due to the dynamic and mutability of the intangible assets, as already explained in this study, also taking into account that the dominated classes, depending on the inferior conditions to which they are subjected, reuse or resignify various assets/goods pertaining to the ruling classes.

118 GUELMAN, Leonardo Caravana. A experiência múltipla de um projeto e seus enraizamentos no território. In: GUELMAN, Leonardo C.; SANTOS, Juliana Amaral dos; GRADELLA, Pedro de Andrea (orgs.). Prospecção e capacitação em Territórios Criativos: desenvolvimento de potenciais comunitários a partir das práticas culturais nos territórios Cariri (CE), Madureira, Quilombo Machadinha e Paraty (RJ). Niterói: CEART; Mundos das Ideias, 2017.
}

In consequence, it is no exaggeration to state that, in this example, it is clear that there is an exhaustion of the ICH category. After all, if one loses political force, meaning that if the policy no longer had the desired effect, as recalled by Gonçalves ${ }^{119}$, is it still useful?

The neutralization of its contending power transforms the ICH into just another notarial averment, reducing intangible heritage to a blue plaque on the wall of a store. As already argued, the ICH is a category with the potential to provide visibility and legitimacy to the struggles of certain vulnerable or historically inferior groups, which is quite different from stating that the ICH belongs to those groups.

\section{Conclusion}

In the present article, it was argued that the entrepreneurial logic, under the aegis of the standard city, appropriated and framed the Carioca ICH. The political dimension of the $\mathrm{ICH}$, which is expressed in the recognition and visibility of the heritage of historically inferior groups, has been drastically reduced. Furthermore, this process concealed the clashes and conflicts that surround and inhabit the field of heritage.

Therefore, it is possible to conclude that the neutralization (although some degree of control and power is still maintained) has drastically reduced the ICH's contending profile. The symbolic strength of this category, however, is lost.

All of these elements are essential to the standard city. The appropriation of the $\mathrm{ICH}$, within the entrepreneurial logic, as defended in this study, triggers a process of erasing the collective memory of historically inferior social groups, leading to invisibility and, therefore, to erasure.

The consequences of applying the ICH under the new driving force of urban entrepreneurship were identified in the third section of this article, through the reference case of Chapelaria Porto. In analyzing this specific case, the damaging effects of this new orientation were clearly evidenced, especially the process of

119 GONÇALVES, José Reginaldo Santos. Os limites do patrimônio. In: LIMA FILHO, Manuel Ferreira; ECKERT, Cornélia; BELTRÃO, Jane (orgs.). Antropologia e patrimônio cultural: diálogos e desafios contemporâneos. Florianópolis: Nova Letra; ABA, 2007. 
erasure effected on those cultural assets that are not in line with the entrepreneurial logic implemented by the Rio Institute of Humanity Heritage in partnership with SEBRAE-RJ.

In this context, the vulnerability of certain assets stakeholders and producers of an intangible nature is aggravated, thus leading, as exemplified by the Chapelaria Porto case, to invisibility and to the erasure of cultural manifestations that fail to comply with the purpose of the local preservation policy.

The thesis presented was that of the contending power held by the ICH (central and structuring aspect of this category) which was overwhelmed and appropriated by the entrepreneurial logic and outlined by the standardization of the city of Rio de Janeiro, thus initiating a process of ruin and erasure of the collective memory of certain individuals, subjects and social groups.

Hence, the results obtained by this work reveal that, considering the chosen context, the Carioca ICH was appropriated by the entrepreneurial logic in the standard city context. Because this category represented an actual possibility of change for those who have been historically subjected to inferiority, this negative appropriation not only nullified the power originally held by the $\mathrm{ICH}$, but also contributed to aggravate the erasure of these vulnerable groups and individuals.

\section{References}

ARANTES, Antônio Augusto (org.). O espaço da diferença. Campinas: Papirus, 2000.

ARANTES, Antônio Augusto. A guerra dos lugares: sobre fronteiras simbólicas e liminaridades no espaço urbano. Revista do Patrimônio Históricos e Artístico Nacional, Brasília, n. 23, 1994.

CANCLINI, Néstor Garcia. O patrimônio cultural e a construção imaginária do nacional. Revista do Patrimônio Histórico e Artístico Nacional, n. 23, p. 95-115, 1994.

CAVALLAZZI, Rosângela Lunaderlli. Cidade Standard: desafios da paisagem em movimento. In: AHMED, Flávio; SOARES, Inês Virgínia Prado (org.). Bens culturais e cidades sustentáveis. Rio de Janeiro: Lumen Juris, 2016.
CAVALLAZZI, Rosângela Lunaderlli. Perspectivas contemporâneas do patrimônio cultural: paisagem urbana e tombamento. In: FERNANDES, Edésio; ALFONSIN, Betânia. Revisitando o instituto do tombamento. Belo Horizonte: Fórum, 2010.

CAVALLAZZI, Rosângela Lunaderlli; AYRES, Madalena Junqueira (org.). Construções normativas e códigos da cidade na Zona Portuária. Rio de Janeiro: PROURB, 2012.

CAVALLAZZI, Rosângela Lunaderlli; FAUTH, Gabriela (coord.). Cidade Standard e novas vulnerabilidades. Rio de Janeiro: PROURB, 2018.

CAVALLAZZI, Rosângela Lunaderlli; RIBEIRO, Cláudio Rezende (org.). Paisagem urbana e direito à cidade. Rio de Janeiro: PROURB, 2010.

CERTEAU, Michel de. A invenção do cotidiano: artes de fazer. 14. ed. Rio de Janeiro: Vozes, 2008. v. 1.

CHOAY, Françoise. A alegoria do patrimônio. São Paulo: Estação Liberdade; UNESP, 2006.

DAMATTA, Roberto. O ofício do etnólogo ou como ter anthropological blues. Boletim do Museu Nacional, n. 27, 1978.

DOMINGUES, João Luiz Pereira. A história institucional recente da política de patrimônio cultural na cidade do Rio de Janeiro: versões protecionistas, versões empreendedoras. Antiteses, v. 9, n. 17, p. 222-245, jan./jun. 2016.

DOMINGUES, João Luiz Pereira; LOPES, Guilherme. Economia Criativa e trabalho cultural: notas sobre as políticas culturais brasileiras e nos marcos do capitalismo contemporâneo. In: RUBIM, Antônio Albino Canelas; BARBALHO, Alexandre; CALABRE, Lia (orgs.). Politicas culturais no governo Dilma. Salvador: EDUFBA, 2015.

GONÇALVES, José Reginaldo Santos. Os limites do patrimônio. In: LIMA FILHO, Manuel Ferreira; ECKERT, Cornélia; BELTRÃO, Jane (orgs.). Antropologia e patrimônio cultural: diálogos e desafios contemporâneos. Florianópolis: Nova Letra; ABA, 2007.

GUELMAN, Leonardo Caravana. A experiência múltipla de um projeto e seus enraizamentos no território. In: GUELMAN, Leonardo C.; SANTOS, Juliana Amaral dos; GRADELLA, Pedro de Andrea (orgs.). Prospeçãa e capacitação em Territórios Criativos: desenvolvimento de potenciais comunitários a partir das práticas culturais nos territórios Cariri (CE), Madureira, Quilombo Ma- 
chadinha e Paraty (RJ). Niterói: CEART; Mundos das Ideias, 2017.

HARVEY, David. A produção capitalista do espaço. São Paulo: Annablus, 2006.

HARVEY, David. Cidades rebeldes: do direito à cidade à revolução urbana. São Paulo: Martins Fontes, 2014.

HARVEY, David. From managerialism to entrepreneurialism: the transformation of urban governance in late capitalism. Geographic Annaler, v. 71B, p. 3-17, 1989.

HOBSBAWM, E.; RANGER, T. A invenção das tradições. Rio de Janeiro: Paz e Terra, 1997.

LEFEBVRE, Henri. O direito à cidade. São Paulo: Centauro, 2010.

REIS, Daniel. Cidade (i)material: museografias do patrimônio cultural no espaço urbano. Rio de Janeiro: Mauad X; FAPERJ, 2015.

RIO DE JANEIRO [Município]. Plano Estratégico da cidade do Rio de Janeiro pós-2016: o Rio mais integrado e competitivo. Rio de Janeiro, 2010.
RUBIM, Antonio Albino Canelas. Políticas culturais e novos desafios. Matrižes, São Paulo, v. 1, n. 2, out. 2009. Disponível em: http://www.matrizes.usp.br/ojs/index.php/matrizes/article/view/18. Acesso em: 10 jan. 2010.

RUBIM, Antonio Albino Canelas. Políticas culturais entre o possível e o impossível. O público e o privado, Fortaleza, n. 9, 2007.

RUBIM, Antonio Albino Canelas. Políticas culturais no Brasil: tristes tradições, enormes desafios. Salvador, 2007.

RUBIM, Antônio Albino Canelas; BARBALHO, Alexandre (orgs.). Politicas culturais no Brasil. Salvador: EDUFBA, 2007.

SOUZA FILHO, Carlos Frederico Marés. Tombamento e registro: dois instrumentos de proteção. In: FERNANDES, Edésio; ALFONSIN, Betânia. Revisitando o instituto do tombamento. Belo Horizonte: Fórum, 2010.

VELHO, Gilberto. Antropologia urbana: interdisciplinaridade e fronteiras do conhecimento. Mana, Rio de Janeiro, v. 17. n. 1, abr. 2011. 
Para publicar na Revista de Direito Internacional, acesse o endereço eletrônico www.rdi.uniceub.br ou www.brazilianjournal.org.

Observe as normas de publicação, para facilitar e agilizar o trabalho de edição. 